\title{
On the spider fauna (Arachnida: Aranei) of the Kanin Peninsula and Kolguev Island, Nenets Autonomous Okrug, Russia
}

\author{
О фауне пауков (Arachnida: Aranei) полуострова Канин \\ и острова Колгуев, Ненеџкий Автономный округ, Россия
}

\begin{abstract}
Anna A. Nekhaeva
Анна А. Нехаева

A.N. Severtsov Institute of Ecology and Evolution, Russian Academy of Sciences, Leninsky prospect 33, Moscow 119071, Russia. E-mail: adrealinea@gmail.com

Институт проблем экологии и эволюции им. А.Н. Северцова РАН, Ленинский пр., 33, Москва, 119071, Россия. E-mail: adrealinea@gmail.com
\end{abstract}

KEY WORDS: biotopic distribution, species list, tundra, Low Arctic, distribution.

КЛЮЧЕВЫЕ СЛОВА: биотопическое распределение, список видов, тундра, низкая Арктика, распространение.

ABSTRACT. The first faunistic data on spiders occurring in the Kanin Peninsula and Kolguev Island, whence only three species were earlier known with certainty, are provided. Species lists consist of 75 and 25 species, respectively. Yet data on habitat preferences of the recorded species are given. A total of 86 species are currently known from the Kanin Peninsula and Kolguev Island. The diversity and activity of spiders in the studied communities are briefly discussed.

How to cite this article: Nekhaeva A.A. 2020. On the spider fauna (Arachnida: Aranei) of the Kanin Peninsula and Kolguev Island, Nenets Autonomous Okrug, Russia // Arthropoda Selecta. Vol.29. No.3. P.387398. doi: 10.15298/arthsel. 29.3.12

РЕЗЮМЕ. Приведены первые фаунистические данные о пауках полуострова Канин и острова Колгуев, откуда ранее достоверно были известны только три вида. Приведены списки, включающие, соответственно, 75 и 25 видов, а также данные об их биотопическом распределении. Всего с полуострова Канин и острова Колгуев в настоящее время известно 86 видов. Кратко обсуждается разнообразие и активность пауков в исследованных сообществах.

\section{Introduction}

The spider fauna of the tundra zone of Russia has been studied extremely unevenly [Marusik, Eskov, 2009]. The European sector seems to be the best studied [Mazura, 2000; Mazura, Esyunin, 2001; Tanasevitch, Koponen, 2007]. The southern tundra of the north-east of Russian Plain comprises at least 216 species [Tanasevitch, Koponen, 2007], which is comparable to the spider diversity of the Siberian tundra accounting for about 230 species [Marusik, Eskov, 2009].
Nevertheless, even here, in a relatively accessible territory, some territories remain absolutely unexplored, for instance, the Kanin Peninsula in Nenets Autonomous Okrug. The only data on spiders from this large terrain available to date were generated by the 1902 Kanin expedition organized by Imperial Russian Geographical Society [Zhitkov, 1904]. The expedition explored the southern part of the Kanin Peninsula from mid-June to mid-August, and the collected spider materials were studied by S.V. Pokrovskiy. Most spiders were taken from the coast of Mezen Bay and only two species originated from the Kanin tundra [Pokrovskiy, 1904]; according to Sergienko [1986], the terrain from where spiders were collected is now considered the south forest-tundra. Since 1902, there have been no further special studies of spiders in the region at hand. The same holds true for Kolguev Island, from where the only species, Hilaira nubigena Hull, 1911, was recorded by Tanasevitch [2017a], despite regular visits of field workers.

The present paper presents results of the first special survey of spider fauna of the Kanin Peninsula and Kolguev Island. Habitat preferences of the recorded species are also included.

\section{Materials and methods}

\section{Studied area}

The Kanin Peninsula is located in the westernmost part of the East European tundra and surrounded by waters of White and Barents Seas. It extends by 292 $\mathrm{km}$ from the south to the north, and its total area is about $18000 \mathrm{~km}^{2}$ [Sergienko, 1986]. Spiders were collected from the vicinity of Shoina (Шойна) Village (c. $67.878254^{\circ} \mathrm{N}, 44.150705^{\circ} \mathrm{E}$ ) (Fig.1). The climate in the region at hand is subarctic, with the annual mean air temperature reaching $-1.6^{\circ} \mathrm{C}$. The mean temperature of 


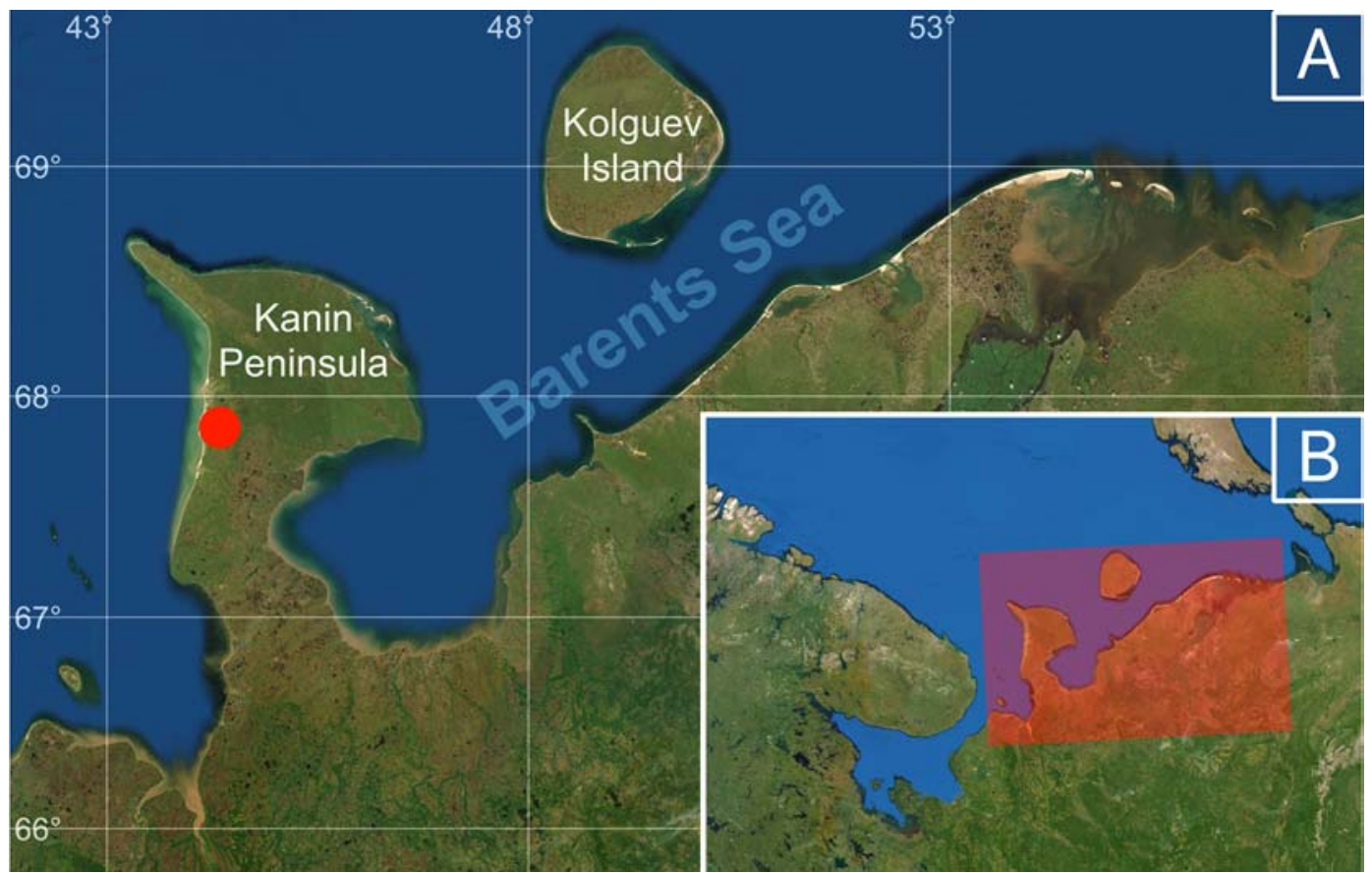

Fig. 1. Map (A) and a view of the studied area (B). The location of Shoina village is indicated with a circle. Рис. 1. Карта (А) и обзор изученного района (В). Расположение поселка Шойна отмечено кругом.

February (the coldest month) is about $-12.1^{\circ} \mathrm{C}$, that of July (the warmest month) reaches $+9.7^{\circ} \mathrm{C}$ [Sergienko, 1986]. The vegetation season, i.e., the period of the mean daily temperatures exceeding $+5^{\circ} \mathrm{C}$, lasts about 106 days [Filippov, Shuvalov, 2006]. The permafrost has no continuous distribution, and its area occupies about $5-25 \%$ of the peninsula; it is absent from river valleys and warmed slopes [Sergienko, 1986, 2013]. The vegetation of the Kanin Peninsula is typical of the tundra zone. In the study area, the bushy tundra (with Betula spp. or willow shrubs) and frost mound bogs predominate. Sand dunes with the typical vegetation occur along seashores. Marshes occur at river mouths and can be temporarily flooded by seawater at high tides [Sergienko, 1986; Filippov, Shuvalov, 2006]. The landscapes near the village are strongly transformed by human activities [Filippov, Shuvalov, 2006], with large areas being covered with sands without vegetation.

Spiders were collected from different biotopes (Table 1), from 12 to 26 July, 2017. The following collecting methods were used: sifting moss and litter, pitfall trapping, sweeping, and hand collecting. The pitfall traps were made of $200 \mathrm{ml}$ plastic cups, 100 $\mathrm{mm}$ high with an opening of $65 \mathrm{~mm}$ in diameter, filled in by one-third with water (in sea marshes and dunes) or $4-8 \%$ formalin solution (in other habitats). The traps on the seashore were checked every three days, and those in other sites weekly. The material was sorted out during the fieldwork and preserved in $98 \%$ ethanol. Then it was transported to the laboratory and identified under a stereomicroscope. The total material accounted for 1290 trap-days; 2985 spider speci- mens were collected, of which 2335 adults were identified to species.

The Kolguev Island is situated to the north-east part of the Kanin Peninsula (Fig.1). Its total area is about $5030 \mathrm{~km}^{2}$. The island is a bogged plain raised in its central part. There is a cluster of low hills $(25-50 \mathrm{~m}$ a.s.1.) with flat tops and gentle slopes in the middle of the island. The average annual air temperature is about $-2.7^{\circ} \mathrm{C}$. The mean temperature in July reaches $+7.6^{\circ} \mathrm{C}$. The duration of vegetation season is about 72 days. The island is situated in the typical tundra subzone of the tundra belt [Makarova, 2012; Lavrinenko, Lavrinenko, 2018].

In $12-28$ July 2019 , the spider material was collected by pitfall traps from the central part of Kolguev Island (c. $69.164304^{\circ} \mathrm{N}, 48.925823^{\circ} \mathrm{E}$ ). The traps were similar to those used in the Kanin Peninsula but with a $2 \%$ formalin solution as a preservative. They were set up in five different habitats: the zonal tundra, a sedge bog in a river valley, snow bed in the dry northern moss-lichen slope, meadow in a dry southern slope, the Dryas tundra. The material was sorted out and identified in the laboratory. The total material accounted for 368 trap-days; 131 spider specimens were collected, of which 108 adults were identified to species.

\section{Museum materials}

In addition to the spiders collected in the field, museum materials from the Kanin Peninsula and Kolguev Island deposited in the Zoological Museum of the Moscow University (ZMMU; Moscow, Russia) were examined (a total of three adult specimens). 
Table 1. Description of the studied habitat types in the vicinities of Shoina village, Kanin Peninsula. Таблица 1. Описание изученных местообитаний в окрестностях села Шойна, п-ов Канин.

\begin{tabular}{|c|c|c|}
\hline Habitat & Dominant plant species & Collecting method \\
\hline $\begin{array}{l}\text { Sea marshes I-IV } \\
\text { (from lowest to upper } \\
\text { level) }\end{array}$ & Carex subspathacea, Puccinellia phryganodes, Plantago sp. & PT (380), HC \\
\hline Willow thicket & Salix sp. & PT (100), HC \\
\hline Sandy banks of streams & Carex spp. & PT (100), $\mathrm{HC}^{1}$ \\
\hline $\begin{array}{l}\text { Sedge brakes on boggy } \\
\text { places }\end{array}$ & Carex spp., Betula nana, Salix sp., green mosses & PT (100), Sif \\
\hline Sphagnous cushions & Sphagnum sp. & Sif \\
\hline Shrub tundra & Salix sp., Betula ?czerepanovii & Sif, Sw \\
\hline Crowberry tundra & $\begin{array}{l}\text { Empetrum hermaphroditum, Betula nana, Vaccinium vitis- } \\
\text { idaea, Arctous alpina, fruticose lichens, green mosses }\end{array}$ & PT (60) \\
\hline Birch thicket & $\begin{array}{l}\text { Betula ?czerepanovii, Salix sp., Geranium sp., Myosotis sp., } \\
\text { Polygonatum sp., Equisetum sp., Trientalis sp. }\end{array}$ & PT (60), Sif, Sw \\
\hline Sandy beaches, dunes & Leymus arenarius & PT (240), HC ${ }^{2}$ \\
\hline $\begin{array}{l}\text { Zonal tundra (dwarf } \\
\text { shrub tundra) }\end{array}$ & $\begin{array}{l}\text { B. nana, Salix sp., Cassiope tetragona, Vaccinium myrtillus, } \\
\text { Geranium sp., Caltha sp., green mosses, Carex spp., } \\
\text { Sphagnum sp. }\end{array}$ & $\begin{array}{l}\text { PT (150), HC, Sif, } \\
\text { Sw }\end{array}$ \\
\hline $\begin{array}{l}\text { Willow-birch shrub } \\
\text { tundra }\end{array}$ & $\begin{array}{l}\text { Salix sp., Vaccinium myrtillus, Empetrum hermaphroditum, } \\
\text { Vaccinium vitis-idaea, Vaccinium uliginosum, B. nana, } \\
\text { Chamaepericlymenum suecicum, Trientalis sp., } \\
\text { Arctostaphylos alpina, Dicranum sp. }\end{array}$ & Sif, Sw \\
\hline Snow bed & Empetrum hermaphroditum, Salix sp., green mosses & PT (100) \\
\hline
\end{tabular}

Abbreviations: HC — hand collecting, PT — pitfall traps, Sif — sifting moss and litter, Sw — sweeping. A number of trap-days for pitfalls is given in parenthesis. ${ }^{1}$ - under snags and in sedge brakes; ${ }^{2}-$ under stones and snags in dunes.

The nomenclature follows WSC [2020]. All the studied material will be deposited in the ZMMU.

\section{Data analysis}

To assess a degree of faunal similarity between different regions of north-eastern Europe, literaturederived data on local spider faunas has been used [Koponen, 1984, with changes; Mazura, 2000, with changes; Tanasevitch, Koponen, 2007; Tanasevitch, Nekhaeva, 2014; Marusik et al., 2016; Tanasevitch, 2017a,b; 2018; Tanasevitch, Khruleva, 2017, with additions; Nekhaeva, 2018a]. A faunistic similarity between local faunas was estimated by using the Kulczyński index for qualitative data in PAST 3.25 [Hammer et al., 2001]. The resemblance matrix was visualized using the UPGMA algorithm. In the calculation of spider activity, all collected individuals were taken into account.

\section{Species list}

Lists of the spiders collected from the Kanin Peninsula (Table 2) and Kolguev Island (Table 3) are pre- sented below. Abbreviations used in the tables are as follows: B - sandy stream banks; BF — birch thickets; Bo - sedge bog; Car — sedge thickets in boggy plots; Du — sandy beaches, dunes; DT — Dryas tundra; ImT - crowberry tundra; M - meadow; SB snow bed; ShT — willow-birch shrubby tundra; SM sea marshes (I-IV levels); Sp - Sphagnum cushions; Wil — willow thicket; ZT — dwarf shrubby tundra (zonal tundra). Species marked with an asterisk $\left(^{*}\right)$ were represented by females only; the species hitherto reported from the region are marked with $\left({ }^{\wedge}\right)$.

\section{Results}

\section{Fauna characteristics}

A total of 86 spider species have been identified, of which 75 were found from the Kanin Peninsula and 24 from Kolguev Island. The species belong to nine families, as follows: Linyphiidae (57 from the Kanin Peninsula; 21 from Kolguev Island), Lycosidae $(7 ; 2)$, Clubionidae $(3 ; 0)$, Thomisidae $(2 ; 1)$, Dictynidae $(2 ; 0)$, 


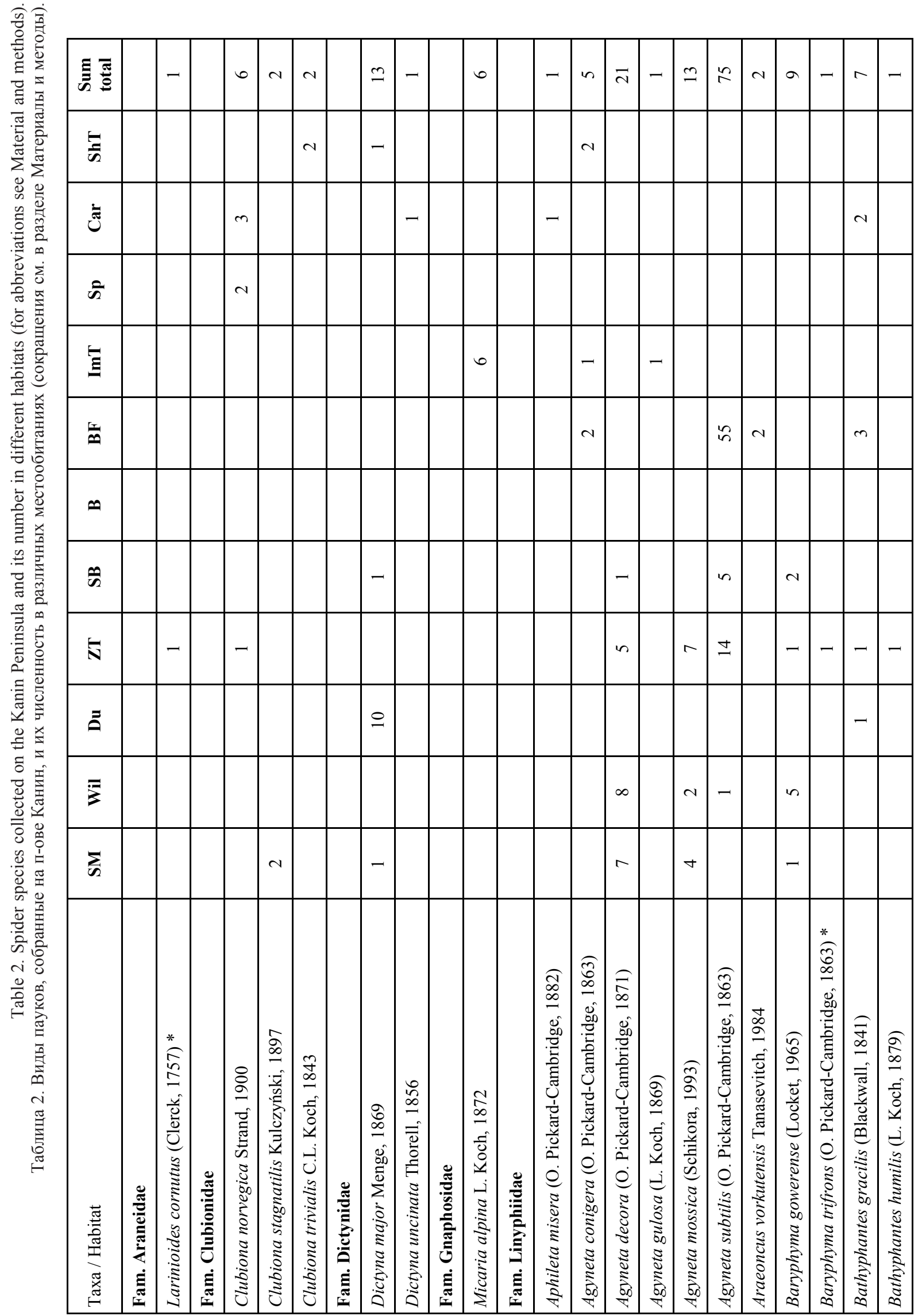




\begin{tabular}{|c|c|c|c|c|c|c|c|c|c|c|c|c|c|c|c|c|c|c|c|c|c|c|c|}
\hline ह & - & - & $r$ & $\nabla$ & - & $\stackrel{\mathbb{N}}{\sim}$ & $\nabla$ & $\nabla$ & oे & 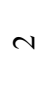 & $a$ & $\simeq$ & 0 & $\cong$ & $\stackrel{\sim}{\sim}$ & $\infty$ & $n$ & $\sim$ & $n$ & $N$ & $m$ & $\hat{\sim}$ & $n$ \\
\hline $\bar{F}$ & & - & & & & - & & & & & & & & & $r$ & & & & & & $m$ & & \\
\hline שี & & & & & & & - & & & & & & & & $\sim$ & $n$ & & & - & - & & & \\
\hline के & & & & & - & & & & & & $\infty$ & & in & $\Xi$ & & & & & $N$ & - & & & \\
\hline 仺 & & & & & & & & & & & & & & & & & & - & & & & & \\
\hline 童 & & & $\nabla$ & & & & & & & & & & & & & - & $n$ & - & & & & & \\
\hline 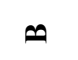 & - & & & & & 8 & & & & & & & & & & & & & & & & $N$ & \\
\hline 光 & & & & & & 움 & $m$ & & & $N$ & & & & & 0 & & & & & & & - & $N$ \\
\hline 5 & & & $m$ & & & & & & & & - & & & - & - & $\nabla$ & & & & & & & - \\
\hline$\overline{\tilde{\theta}}$ & & & & $N$ & & in & & & in & & & - & & & $m$ & & & & & & & $\stackrel{0}{-}$ & \\
\hline $\bar{z}$ & & & & - & & J & & - & 0 & & & & & & - & & & & & & & $\infty$ & \\
\hline$\sum_{\infty}$ & & & & - & & $a$ & & $m$ & $\stackrel{\curvearrowright}{\curvearrowright}$ & & & $=$ & - & & & & & & & & & & \\
\hline & 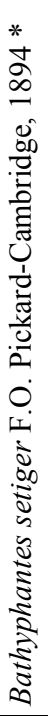 & 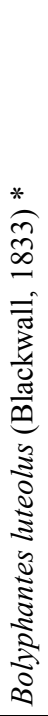 & 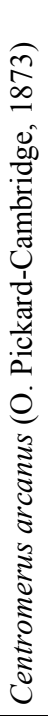 & 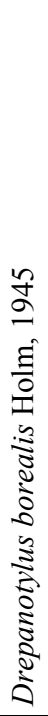 & 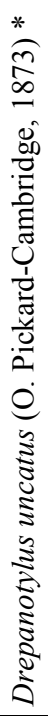 & 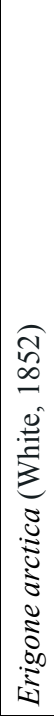 & 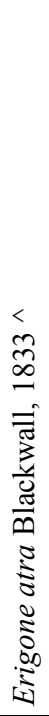 & 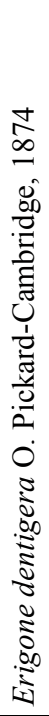 & 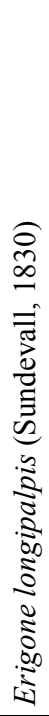 & 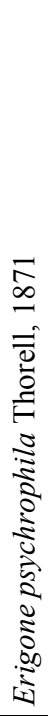 & 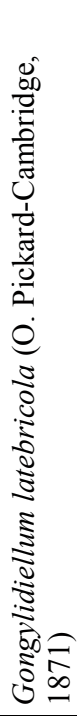 & 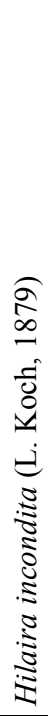 & 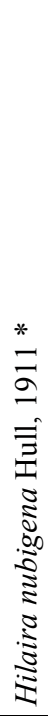 & 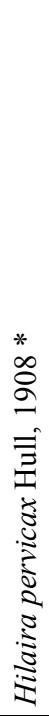 & 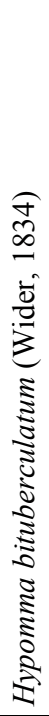 & 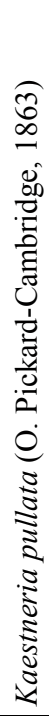 & 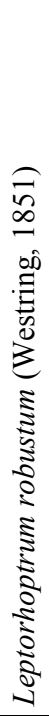 & 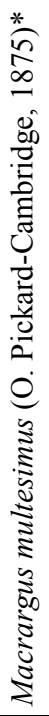 & 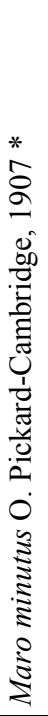 & 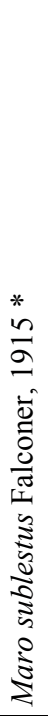 & 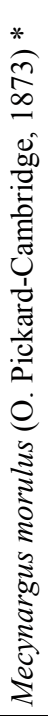 & 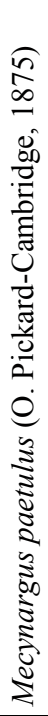 & 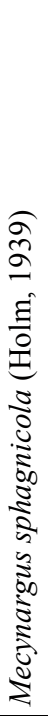 \\
\hline
\end{tabular}




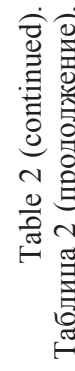

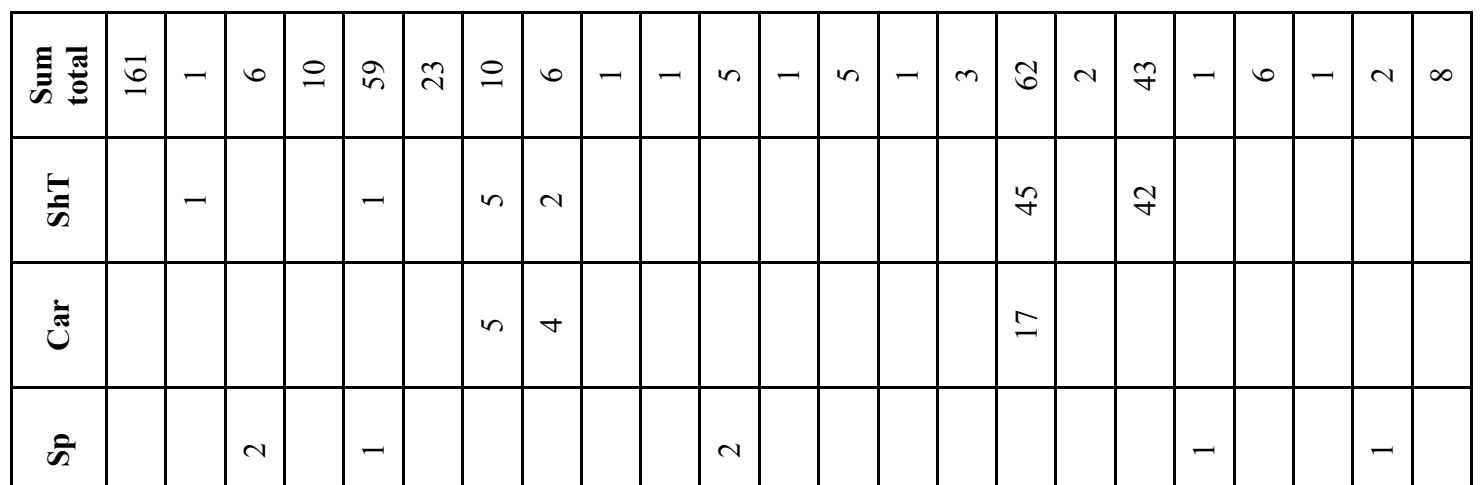

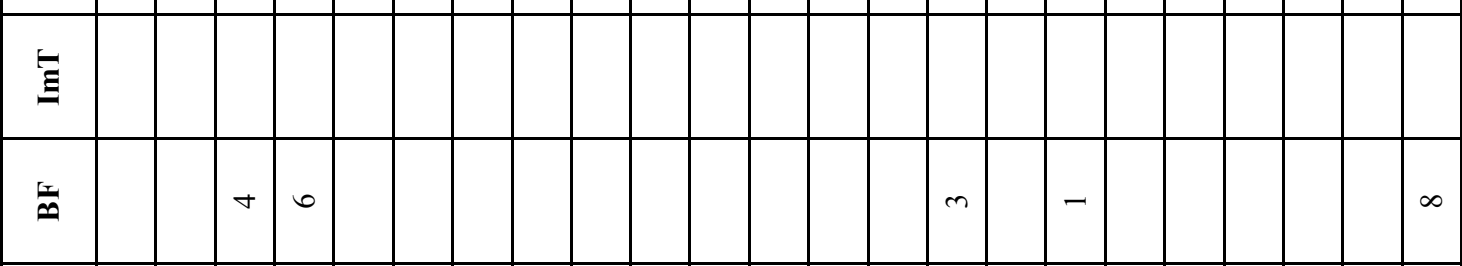

$\infty$

कै

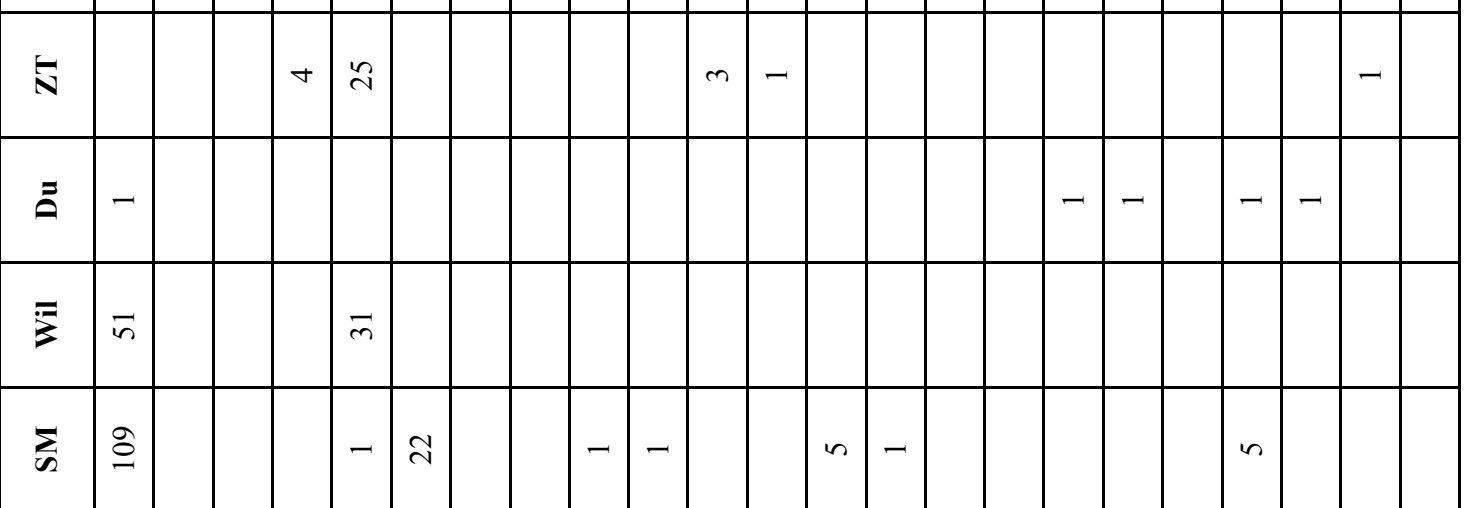

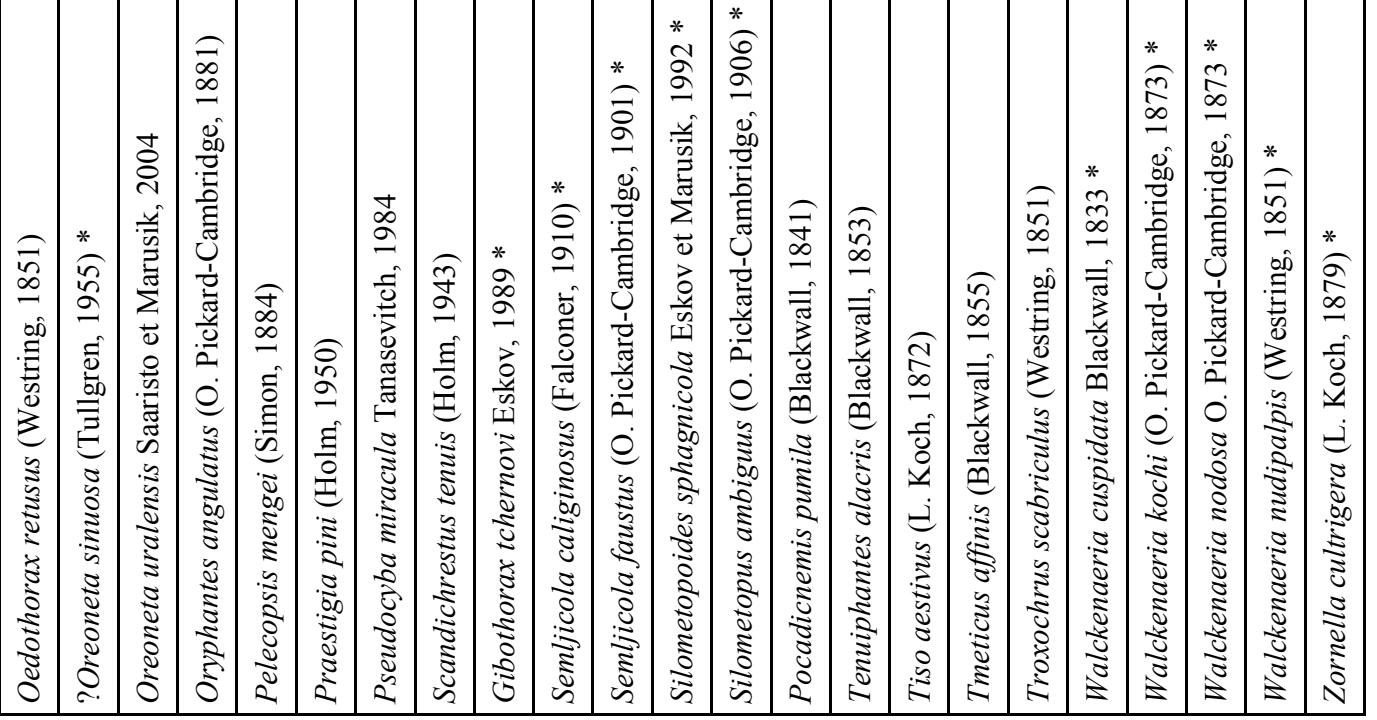




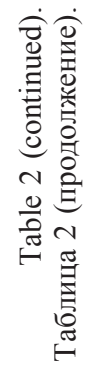

\begin{tabular}{|c|c|c|c|c|c|c|c|c|c|c|c|c|c|}
\hline 音 & $n$ & $\approx ૂ$ & & $a$ & શे & - & $\nabla$ & $\nabla$ & $n$ & n & $m$ & $\begin{array}{l}\bar{n} \\
\tilde{n}_{0}\end{array}$ & 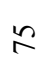 \\
\hline 章 & & & & & & & & & & $m$ & & $\underset{0}{=} \tilde{n}$ & $\Xi$ \\
\hline نَ & & & $\sim$ & & & & & & - & - & & $\stackrel{n}{*}=$ & 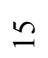 \\
\hline के & & & & & & & & & & $N$ & & 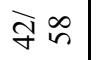 & $\stackrel{m}{=}$ \\
\hline$\overline{\mathrm{g}}$ & & & & & $\grave{\sim}$ & & & & & - & $m$ & ò 0 & $r$ \\
\hline 空 & & & & & & & & & & & & 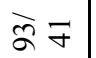 & 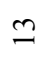 \\
\hline$\infty$ & & - & & & & & & - & & & & $\approx n$ & $n$ \\
\hline 光 & - & $\sim$ & $\sim$ & & $N$ & & & & & $m$ & & $\underset{I}{I} n$ & 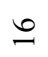 \\
\hline 5 & & & 6 & $a$ & & - & $m$ & & & 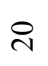 & & $\stackrel{0}{=} \approx$ & $\approx$ \\
\hline $\bar{\Xi}$ & & - & & & & & & $N$ & & & & $\Xi n$ & 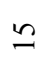 \\
\hline 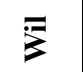 & $N$ & $\frac{m}{m}$ & - & & & & & & $N$ & $N$ & & बे $n$ & $\beth$ \\
\hline$\sum_{\infty}$ & & $\stackrel{\infty}{0}$ & 0 & & & & - & - & $N$ & & & $\underset{\varrho}{\Xi}$ & さ \\
\hline
\end{tabular}

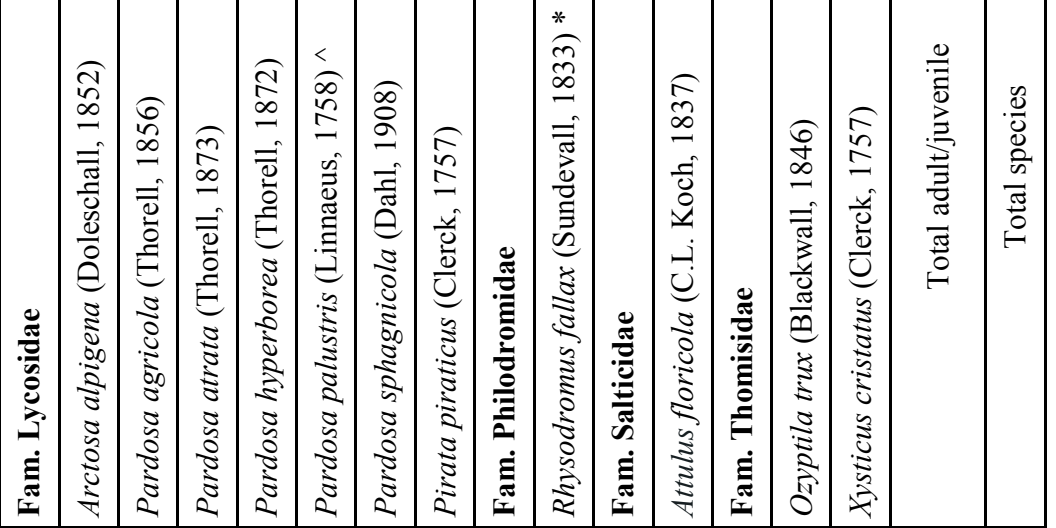


Philodromidae $(1 ; 0)$, Salticidae $(1 ; 0)$, Gnaphosidae $(1 ; 0)$, Araneidae $(1 ; 0)$.

Among the collected species, only Erigone atra Blackwall, 1833 (1 +, ZMMU Ta-3593) was previously reported from Parusnoe Lake [Pokrowsky, 1904: 305] (Table 2). Another species, which was also collected by the 1902 Kanin expedition - Pardosa albatula (Roewer, 1951) [Pokrowsky, 1904: 306, sub Lycosa albata] - was not found in the ZMMU collection. Only three females of the latter species were collected in 1902, and therefore it is likely that they could have been misidentified and seemed to belong to Pardosa palustris (Linnaeus, 1758).

The only spider species known from Kolguev Island before the present study was Hilaira nubigena [Tanasevitch, 2017a: 80]. Yet, two specimens of Erigone arctica (White, 1852) collected from there at the beginning of the last century were found in the ZMMU collection (Table 3). Along with the latter species, all the remaining species (see Tables) have been reported from the Kanin Peninsula and Kolguev Island for the first time. Comments on distribution of some of them are provided below.

Linyphiidae

Agyneta ripariensis Tanasevitch, 1984. Described from the Bolshezemelskaya tundra and the Polar Urals;

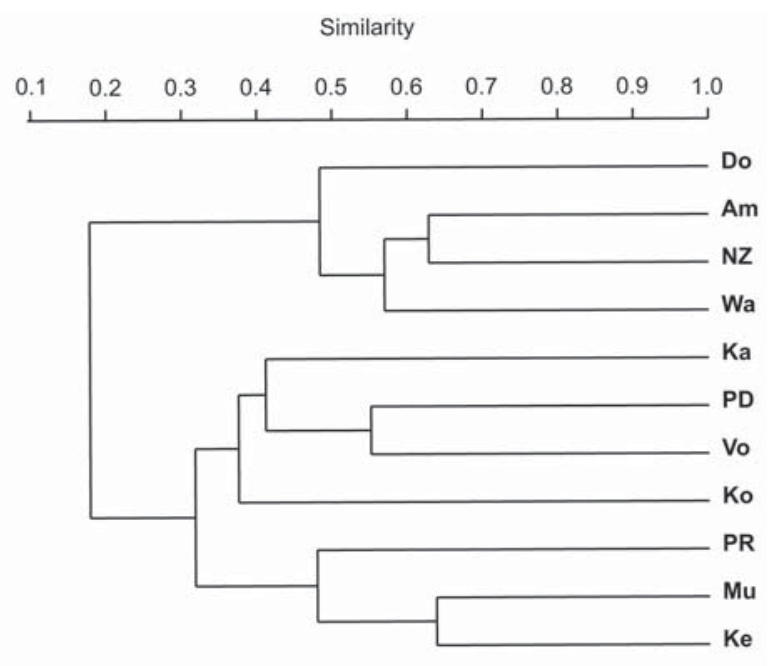

Fig. 2. Dendrogram comparing local spider faunas of northeast Europe. Abbreviations: Amderma Vil. vicinities, Yugorsky Peninsula (Am); Dolgiy Island (Do); vicinity of Shoina Vil., Kanin Peninsula (Ka); Kevo Subarctic Research Station, Finland (Ke); Kolguev Island (Ko); Murmansk vicinity, Kola Peninsula (Mu); Novaya Zemlya (NZ); Pechora Delta (PD); Pinezhskiy Nature Reserve, Arkhangelsk region (PR); Vorkura vicinity, Komi Republic (Vo); Waigach Island (Wa).

Рис. 2. Дендрограмма сходства локальных фаун пауков северо-восточной Европы. Сокращения: окрестности пос. Амдерма, Югорский полуостров (Am); о. Долгий (Do); окрестности пос. Шойна, полуостров Канин (Ka); окрестности Субарктической научной станции Кево, Финляндия (Ke); о. Колгуев $(\mathrm{Ko})$; окрестности г. Мурманск, Кольский полуострова (Mu); Новая Земля (NZ); дельта р. Печора (PD); заповедник «Пинежский», Архангельская область (PR); окрестности г. Воркута, Республика Коми (Vo); о. Вайгач (Wa). it is a Siberian arcto-boreal species, occurring from Doldiy Island to Chukotka, southward to the upper Kolyma River [Eskov, 1994; Marusik et al., 2016]. The present finding in Kolguev Island lies at the westernmost limit of the species range.

Araeoncus vorkutensis Tanasevitch, 1984 was described and repeatedly recorded from the southern tundra of Russian Plain [Tanasevitch, Koponen, 2007]. The Pinezhskiy Nature Reserve (Arkhangelsk Area) represents the westernmost limit of its range [Tanasevitch, Nekhaeva, 2014], whereas Kolguev Island is the north-westernmost locality of this Siberian species.

Bathyphantes humilis (L. Koch, 1879). This Siberian hypoarcto-nemoral species is known from the northeast part of Russian Plain to the Russian Far East [Eskov, 1994; Tanasevich, Koponen, 2007; Marusik, Eskov, 2009; Tanasevitch, Khruleva, 2017]. The White Sea coast of the Kanin Peninsula represents the westernmost locality of the species.

Gibothorax tchernovi Eskov, 1989. This species was previously known from Dolgiy Island to Chukotka [Eskov, 1994; Marusik et al., 2016; Tanasevitch, Khruleva, 2017]. One female was collected from sea marshes of the Kanin Peninsula, representing the westernmost record of the species.

Hilaira incondita (L. Koch, 1879). The White Sea coast of the Kanin Peninsula is the westernmost locality of this Siberian-Nearctic species [Marusik, Nekhaeva, 2020].

Pseudocyba miracula Tanasevitch, 1984. This species was described from the south-east part of the Bolshezemelskaya tundra. It has a trans-Siberian range [Eskov, 1994; Marusik, Eskov, 2009]. The present finding in the White Sea coast of the Kanin Peninsula represents its westernmost record.

Silometopoides sphagnicola Eskov et Marusik, 1992. A single female was collected. This Siberian species was recently found in the Yugorsky Peninsula [Tanasevitch, Khruleva, 2017; own unpublished data]. Hence, the White Sea coast of the Kanin Peninsula represents the westernmost locality of the species.

Silometopus ambiguus (O. Pickard-Cambridge, 1906). This species has a European range [Tanasevitch, Koponen, 2007; Marusik, Eskov, 2009], with the Kanin Peninsula lying at its northernmost limit.

Troxochrus scabriculus (Westring, 1851). A EuroYenisei boreo-nemoral species [Eskov, 1994; Marusik et al., 2000]; the present record from the Kanin Peninsula lies at the northernmost limit of the species range.

\section{Philodromidae}

Rhysodromus fallax (Sundevall, 1833). This species has a Palaearctic range [Marusik et al., 2000]. The White Sea coast of the Kanin Peninsula is the northernmost locality for the species.

The spider faunas of both studied terrains mainly consist of widespread species. The Holarctic and Palaearctic groups were most abundant, accounting for 35\% 

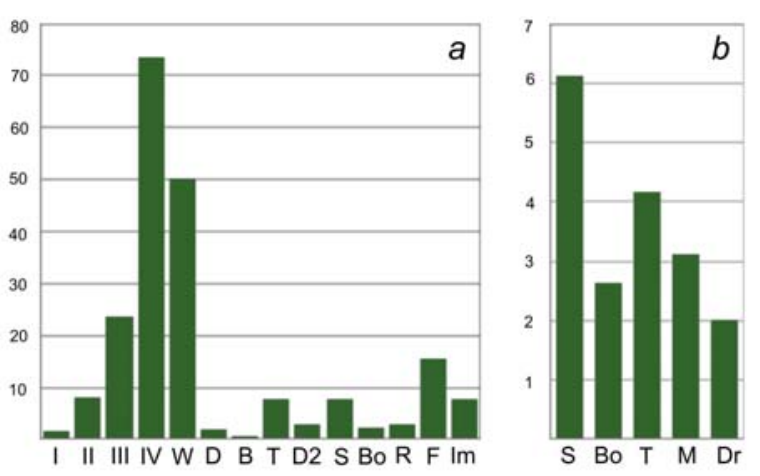

Fig. 3. Spider activity (ind./10 trap-days) in the studied biotopes of the Kanin Peninsula (a) and Kolguev Island (b). All collected specimens are taken into account; notice the discrepancy in figure scales. Abbreviations: I-IV - sea marsh levels (from low to high, i.e. the most distant from water), B - sandy beach, Bo - sedge bog, D - dunes, D2 - sandy area among the tundra, Dr - Dryas tundra, F - birch thickets, Im - crowberry tundra, M - meadow, $\mathrm{R}$ - sandy bank of the stream, $\mathrm{S}$ - snow bed, $\mathrm{T}$ - zonal tundra, $\mathrm{W}$ - willow shrubs thicket.

Рис. 3. Активность пауков (экз./10 лов.-сут.) в обследованных биотопах полуострова Канин (а) и о. Колгуев (b). Учтены все собранные экземпляры; обратите внимание на несовпадение в шкале рисунков. Сокращения: I-IV - уровни маршей (от низкого к высокому и наиболее удаленному от воды), В песчаный пляж, Во - осоковое болото, D - дюны, D2 песчаный участок среди тундры, $\mathrm{Dr}$ - дриадник, F - заросли березы, Im - воронично-березковая тундра, M - луг, R песчаный берег ручья, $\mathrm{S}$ - снежник, T - зональная тундра, $\mathrm{W}-$ ивняк вдоль берега моря.

and $37 \%$ for the Kanin Peninsula, and $48 \%$ and $20 \%$ for Kolguev Island. Species with the Siberian range made up only $8 \%$ and $12 \%$ respectively. No species with the European range were found in Kolguev Island, while they account for $15 \%$ of the spider fauna of the Kanin Peninsula.

According to a latitudinal component, species that are widespread across the forest zone were most numerous: in the Kanin Peninsula, $48 \%$ and $39 \%$ of spiders were of boreo-nemoral and boreal distribution; in Kolguev Island, 20\% and 44\% correspondingly. Only $5 \%$ of the spider species from the mainland have an arctic or arcto-boreal distribution. In Kolguev Island, such species accounted for $28 \%$.

\section{Comparison with neighbouring areas}

By the spider fauna composition, the Kanin Peninsula and Kolguev Island are similar to that of the northeast tundra of Russian Plain. Together with local faunas of Fennoscandia, they form a cluster separated from the less diverse but more specific fauna of extreme northwest Siberia (Fig. 2).

Spider diversity and abundance in studied communities

A species number in each habitat varied from 5 to 25 in the Kanin Peninsula, and only 5 to 8 (almost equal) in Kolguev Island. In the former site, the least diversity was found along stream sandy banks ( 5 spe- cies) and in the crowberry tundra (7), as compared to sea marshes and dwarf shrubby tundra (24 and 25, respectively) (Table 2).

The studied biotopes cannot be correctly compared by the number of collected specimens due to different sampling efforts and technique. However, the activity (number of individuals per 10 trap-days) can be used for that purpose. In the mainland, it ranged from 2 to 74 ind./10 trap-days in sea marshes, reaching its maximum at the farthest levels from the water (Fig. 3a). A high spider activity (50 ind./10 trap-days) was also detected in willow shrub thickets surrounding marshes by a narrow strip. Its minimum values were in contrasting habitats such as sandy beach or dunes and sandy stream bank and bog (0.5-3 ind./10 trap-days). In the rest of habitats, spider activity varied from 8 to 16 ind./ 10 trap-days. The minimum activity in Kolguev Island was also recorded in the Dryas tundra and the bog (2-3 ind./10 trap-days), i.e. both in the driest and in wettest communities (Fig. 3b).

\section{Discussion}

Based on both new and literature-derived data, the spider faunas of the Kanin Peninsula and Kolguev Island consist of 75 and 25 species respectively, of which 73 and 24 species have been reported from these regions for the first time. Obviously, the species lists are incomplete. Ten species found in Kolguev Island (Pardosa septentrionalis, Agyneta nigripes, A. ripariensis, Collinsia holmgreni, Gonatium rubens, Horcotes strandi, Mecynargus borealis, Semljicola angulatus, Walckenaeria clavicornis, Xysticus canadensis) were not found in the Kanin Peninsula. Yet, all of them have been previously reported from other islands of Barents Sea or from the mainland [Mazura, 2000; Mazura, Esunin, 2001; Tanasevitch, Koponen, 2007; Marusik et al., 2016; Tanasevitch, 2017a,b; etc.]. The number of spider species in some Low Arctic local faunas is higher than that of the Kanin Peninsula. For instance, 163 species are known from the Kevo Subarctic Research Station, the forest-tundra belt of Finland [Koponen, 1984, with changes], 141 - from the vicinity of Murmansk, the forest-tundra belt [Nekhaeva, 2018a], 110 - from Pechora Delta and the adjacent tundra [Mazura, 2000, with changes], 123 - from the vicinity of Vorkuta, the tundra belt [Tanasevitch, Koponen, 2007], etc. Based on the faunal similarities of these territories (Fig. 2), the spider fauna of the Kanin Peninsula should be at least 1.5 times more diverse. Among the explored islands of Barents Sea, Kolguev Island is the second most spider-diverse following Dolgiy Island that comprises 52 recorded species [Marusik et $a l ., 2016]$. Taking into account the island size and its proximity to the mainland, the known species number is likely to increase after a more detailed survey.

The spider fauna, as well as those of other arthropods (ground beetles, lepidopterans), of the northeast European region is known to have a migratory charac- 
Table 3. Spiders species collected on the Kolguev Island and its number in different habitats (for abbreviations see Material and methods).

Таблица 3. Виды пауков, собранные на о. Колгуев, и их численность в различных местообитаниях (сокращения см. в разделе Материалы и методы).

\begin{tabular}{|c|c|c|c|c|c|c|}
\hline Taxa & SB & Bo & ZT & M & DT & Sum total \\
\hline \multicolumn{7}{|l|}{ Fam. Linyphiidae } \\
\hline Agyneta gulosa (L. Koch, 1869) & & & & 2 & & 2 \\
\hline Agyneta nigripes (Simon, 1884) & & & & & 5 & 5 \\
\hline Agyneta ripariensis Tanasevitch, 1984 & & & 1 & & 1 & 2 \\
\hline Araeoncus vorkutensis Tanasevitch, 1984 & 4 & & & & & 4 \\
\hline Collinsia holmgreni (Thorell, 1871) & 10 & & & & & 10 \\
\hline Erigone atra Blackwall, 1833 & 16 & 3 & & 1 & & 20 \\
\hline Erigone psychrophila Thorell, $1871 *$ & & 1 & & & & 1 \\
\hline Gonatium rubens (Blackwall, 1833) * & & & 1 & & 1 & 2 \\
\hline Hilaira nubigena Hull, $1911^{\wedge}$ & & 4 & & & & 4 \\
\hline Horcotes strandi (Sytshevskaja, 1935) & & & 2 & & 2 & 4 \\
\hline Leptorhoptrum robustum (Westring, 1851) & & & & 3 & & 3 \\
\hline Mecynargus borealis (Jackson, 1930) & & & 2 & & & 2 \\
\hline Mecynargus paetulus (O. Pickard-Cambridge, 1875) & 1 & & & & & 1 \\
\hline Mecynargus sphagnicola $(\mathrm{Holm}, 1939)$ & 1 & 7 & & & & 8 \\
\hline Mecynargus monticola (Holm, 1943) * & & & 1 & & & 1 \\
\hline Oreoneta uralensis Saaristo et Marusik, 2004 & 4 & & & & & 4 \\
\hline Pelecopsis mengei (Simon, 1884) * & & & & 3 & & 3 \\
\hline Semljicola angulatus (Holm, 1963) & 3 & 1 & & & & 4 \\
\hline Tiso aestivus (L. Koch, 1872) & 1 & & & 15 & & 16 \\
\hline Walckenaeria clavicornis (Emerton, 1882)* & & & & & 2 & 2 \\
\hline Walckenaeria cuspidata Blackwall, 1833 * & & 1 & & & & 1 \\
\hline \multicolumn{7}{|l|}{ Fam. Lycosidae } \\
\hline Pardosa palustris (Linnaeus, 1758) & & & 1 & & & 1 \\
\hline Pardosa septentrionalis (Westring, 1861) & & & 6 & & & 6 \\
\hline \multicolumn{7}{|l|}{ Fam. Thomisidae } \\
\hline Xysticus canadensis Gertsch, 1934 & & & 2 & & & 2 \\
\hline Total adult/juvenile & $40 / 9$ & $17 / 4$ & $16 / 4$ & $24 / 1$ & $11 / 5$ & $108 / 23$ \\
\hline Total species & 8 & 6 & 8 & 5 & 5 & 24 \\
\hline
\end{tabular}

N.B. Erigone arctica (White, 1852) found in the ZMMU collections is not included in the table. Material: 1 \%, ZMMU Ta-1669, Kolguev Isl., Bugrino Vil., 3.09.1902, leg. S.A. Buturlin (det. as Erigone dentipalpis); 1 ○, ZMMU Ta-1771, Kolguev Isl., estuary of Vas'kina R., 3.08.1902, leg. S.A. Buturlin (det. as Erigone atra). 
ter. It is formed and continues to be formed by the species penetrating it both from the west and from the east [Tanasevitch, Koponen, 2007; Bolotov, 2011; Tatarinov, 2016; Kolesnikova et al., 2017]. The same holds true to the studied terrains where widespread species with boreo-nemoral and boreal distribution predominate. New findings expand the known distributional ranges of A. ripariensis, Bathyphantes humilis, Gibothorax tchernovi, Hilaira incondita, Pseudocyba miracula and Silometopoides sphagnicola westwards. However, compared to the territories lying to the east of the studied region, the proportion of species with Siberian ranges is minimal. It was only 8 and $12 \%$ in the araneofaunas of the Kanin Peninsula and Kolguev Island respectively, whereas such species account for $18 \%$ of the spider fauna of Pechora Delta [Mazura, 2000], 37\% in the vicinity of Vorkuta [Tanasevitch, Koponen, 2007], 42\% in Dolgiy Island [Marusik et al., 2016], and $54 \%$ in the vicinity of Amderma [Tanasevitch, Khruleva, 2017].

The spider diversity and abundance in the studied habitats of Kolguev Island are low and are not further discussed here. The species number found in the Kanin sea marshes (24) was comparable to that in the zonal tundra (25), and their share in the local fauna was $32 \%$ (Table 2). Many of these species were not found outside the marshes (Clubiona stagnatilis, G. tchernovi, Pocadicnemis pumila, Semljicola caliginosus, Silometopus ambiguus). Other species were also abundant in the surrounding willow thickets but rare or absent from other habitats (Erigome dentigera, E. longipalpis, $H$. incondita, Oedothorax retusus, Pardosa agricola, Praestigia pini, Walckenaeria kochi), or they also inhabited moist biotopes such as bogs, stream banks, etc. (Erigone arctica, but notice that on beaches it was restricted to seaweed clusters). Nevertheless, to date, no spider species restricted exclusively to the coast have been known from the (Sub)Arctic. There are only few specific forms occurring in a variety of over-moistened habitats; on sea marshes, they are particularly common. For example, E. longipalpis and E. remota L. Koch, 1869, which substitutes for the former species in the east, are especially abundant in these communities [Marusik et al., 2019]. In other habitats, both of them are scarce. This seems to also be true of other representatives of the genus Erigone, as well as of Masikia, Oedothorax, some Hilaira and Pardosa.

One of the features of coastal habitats is an increased spider activity as compared to other biotopes [Palmgren, 1972; Nekhaeva, 2018a]. On the coastal profile of the Kanin Peninsula, spider activity increased following a change in the hypsometric level (Fig. 3a). Its values at the highest level were at least 1.5 times greater than in other biotopes (cf. 74 ind./10 trap-days here vs. 50 and 2 ind./10 trap-days respectively in willow shrub thickets and sedge bog). A similar pattern was observed both in Western Siberia [Nekhaeva, 2018b] and northern Chukotka (unpublished data).
Acknowledgements. I am very grateful to my colleague Anatoly Babenko (Moscow, Russia) for the help in collecting and processing the material from the Kanin Peninsula. I also wish to express my gratitude to the administration of Shoyna Village for providing comfortable living and working conditions. I am very grateful to Olga Makarova (Moscow, Russia), by whose initiative spiders from Kolguev Island were collected. Special thanks go to A.V. Kondratyev (Magadan, Russia) and P.M. Glazov (Moscow, Russia) for collecting spiders on the island. I thank Kirill Mikhailov (ZMMU, Moscow, Russia) for providing me access to spider collections. I am grateful to Yuri Marusik (Magadan, Russia) for useful comments on the manuscript. The English of the final draft was edited by D.V. Logunov (Manchester, UK). The study was supported by the Russian Foundation for Basic Research, Project \# 17-04-01603.

\section{References}

Bolotov I.N. 2011. [Fauna and ecology of butterflies (Lepidoptera, Rhopalocera) from KaninPeninsula and Kolguev Island] // Zoologicheskiy Zhurnal. Vol.90. No.11. P.1365-1373 [in Russian with English summary].

Eskov K.Yu. 1994. Catalogue of the linyphiid spiders of northern Asia (Arachnida, Araneae, Linyphiidae). Sofia-Moscow: Pensoft Publishers. 144 p.

Filippov B.Yu., Shuvalov E.V. 2006. [Ground beetles in the Southern Tundra of the Kanin Peninsula] // Vestn. Pomorsk. univ., Ser. Estestv. i Tochn. nauki. No.1. P.99-109 [in Russian with English summary].

Hammer Ø., Harper D.A.T., Ryan P.D. 2001. PAST: Paleontological statistics software package for education and data analysis // Palaeontologia Electronica. Vol.4. No.1. P.1-9.

Kolesnikova A.A., Dolgin M.M., Konakova T.N. 2017. [Ground Beetles (Coleoptera, Carabidae)] // Fauna evropeyskogo Severo-Vostoka Rossii. Vol.8. No.4. Syktyvkar: IB Komi SC UrB RAS. 340 p. [In Russian]

Koponen S. 1984. Araneae of Inari Lapland // Kevo Notes. Vol.7. P.15-21.

Lavrinenko O.V., Lavrinenko I.A. 2018. [Zonal vegetation of the plain East European tundras] // Rastitel'nost Rossii. No.32. P.35-108 [in Russian with English summary].

Makarova O.L. 2012. [Gamasid mites (Parasitiformes, Mesostigmata) of the European Arctic and their distribution patterns] // Zoologicheskiy Zhurnal. Vol.91. No.8. P.907-927 [in Russian with English summary].

Marusik Yu.M., Eskov K.Y. 2009. Spiders (Arachnida: Aranei) of the tundra zone of Russia // S.I. Golovatch, O.L. Makarova, A.B. Babenko, L.D. Penev (eds.). Species and communities in extreme environments. Festschrift towards the 75th Anniversary and a laudatio in honour of academician Yuri Ivanovich Chernov. Sofia-Moscow: Pensoft Publishers \& KMK Scientific Press. P.131-164.

Marusik Yu.M., Koponen S., Makarova O.L. 2016. A survey of spiders (Araneae) collected on the arctic island of Dolgiy $\left(69^{\circ} 12^{\prime} \mathrm{N}\right)$, Barents Sea // Arachnology. Vol.17. No.1. P.1024.

Marusik Yu.M., Logunov D.V., Koponen S. 2000. Spiders of Tuva, South Siberia. Magadan: IBPN FEB RAS. 252 p.

Marusik Yu.M., Nekhaeva A.A., Koponen S. 2019. On four sibling Erigone species occurring in the Arctic (Aranei: Linyphiidae) // Arthropoda Selecta. Vol.28. No.1. P.135-146.

Marusik Yu.M., Nekhaeva A.A. 2020. Redescription of two poorly known Arctic Hilaira species (Aranei: Linyphiidae) with notes on species grouping // Arthropoda Selecta. Vol.29. No.1. P.133140.

Mazura N.S. 2000. 6.6. Spiders // Pechora Delta: Structure and dynamics of the Pechora Delta Ecosystems (1995-1999). Syktyvkar, Ledystad. P.133-137.

Mazura N.S., Esyunin S.L. 2001. Fauna and biotopic distribution of the spiders (Arachnida: Aranei) in the tundra zone of the 
North-East of Russian Plain // Arthropoda Selecta. Vol.10. No.1. P.75-81.

Nekhaeva A.A. 2018a. [Spider (Arachnida, Aranei) fauna and population of the Kola Peninsula]. Moscow. PhD thesis. 239 p. [In Russian]

Nekhaeva A.A. 2018b. Spiders (Arachnida, Aranei) of the High Arctic Shokalsky Island $\left(73^{\circ} \mathrm{N}\right)$, the Kara Sea, Russia // Arthropoda Selecta. Vol.27. No.4. P.367-372.

Palmgren P. 1972. Studies on the spider populations of the surroundings of the Tvarminne Zoological Station, Finland // Commentationes Biologicae. Societas Scientiarum Fennica. Vol.52. P.1-133.

Pokrovskiy S.V. 1904. [Spiders collected by the Kanin expedition] // Zapiski Imperatorskogo Russkogo Geograficheskogo Obshchestva po obshchey geografii. Vol.41. No.1. P.295-310 [in Russian].

Sergienko V.G. 1986. [Flora of the Kanin Peninsula]. Leningrad: Nauka Publ. 148 p. [In Russian]

Sergienko V.G. 2013. [Concrete flora of the Kanin-Mezen Region]. Moscow - Saint-Petersburg: KMK Scientific Press Ltd. 180 p. [In Russian]

Tanasevitch A.V. 2017a. New records of spiders (Aranei) from the Russian Arctic // Arthropoda Selecta. Vol.26. No.1. P.77-82.

Tanasevitch A.V. 2017b. Spiders (Aranei) of the Novaya Zemlya Archipelago and the Vaygach Island, Russia // Arthropoda Selecta. Vol.26. No.2. P.145-153.
Tanasevitch A.V. 2018. New data on spiders (Aranei) from the Novaya Zemlya Archipelago and Siberian Arctic, Russia // Arthropoda Selecta. Vol.27. No.1. P.69-71.

Tanasevitch A.V., Khruleva O.A. 2017. Spiders (Aranei) of the typical tundra subzone of the Yugorsky Peninsula, Russia // Arthropoda Selecta. Vol.26. No.4. P.341-368.

Tanasevitch A.V., Koponen S. 2007. Spiders (Aranei) of the southern tundra in the Russian Plain // Arthropoda Selecta. Vol.15. No.4. P.295-345.

Tanasevitch A.V., Nekhaeva A.A. 2014. [Preliminary results of araneological research in the Pinezhskiy Nature Reserve (Arachnida, Aranei)] // Sokhranenie i izuchenie geo- i bioraznoobraziya na OOPT Evropeyskogo Severa Rossii. Materialy nauchno-prakticheskoy konferencii, posvyashchennoy 40-letiyu zapovednika "Pinezhskiy", 2-5 September 2014 ã. PinegaIzhevsk. P.204-207 [in Russian].

Tatarinov A.G. 2016. [Geography of diurnal lepidopterans of the European north-east of Russia]. Moscow: KMK Scientific Press. 255 p. [In Russian]

WSC 2020. World Spider Catalog. Version 21.0. Natural History Museum Bern, online at http://wsc.nmbe.ch

Zhitkov B.M. 1904. [Along the Kanin tundra]. // Zapiski Imperatorskogo Russkogo Geograficheskogo Obshchestva po obshchey geografii. Vol.41. No.1. P.1-170 [in Russian].

Responsible editor D.V. Logunov 